\title{
IMPLEMENTASI SELF-REGULATED LEARING PADA APLIKASI PEMBELAJARAN MANAJEMEN PROYEK SISTEM INFORMASI PADA PERGURUAN TINGGI SWASTA X DI JAKARTA
}

\author{
Kelvin Febrianto ${ }^{1}$, Yunus Fadhillah ${ }^{2}$ \\ Program Studi Teknik Informatika \\ Institut Bisnis dan Informatika Kwik Kian Gie

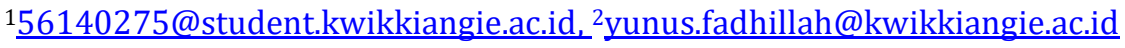

\begin{abstract}
Abstrak
Pengerjaan proyek Sistem Informasi masih mengalami kegagalan dan kerugian dalam beberapa tahun belakangan ini. Maka dari itu pemahaman konsep Manajemen Proyek haruslah diajarkan dalam perkuliahan. Dari hasil analisa perkuliahan yang diadakan pada perguruan tinggi swasta X di Jakarta selama sepuluh tahun silam ini menunjukkan kesenjangan antara hasil belajar harian dengan nilai ujian yang mahasiswa dapatkan. Sehingga harus ada sebuah proses belajar baru yang memperkuat pemahaman mahasiswa terhadap konsep Manajemen Proyek. Metode Self-Regulated Learning (SRL) berfokus pada pembelajaran mandiri melalui metakognisi, motivasi, pengaturan diri, dan evaluasi diri. Untuk mendorong proses belajar tersebut membutuhkan sebuah alat bantu dalam proses belajar. Spesifikasi alat belajar tersebut membutuhkan terciptanya proses metakognisi dengan mengarahkan langkah-langkah belajar secara jelas dan memotivasi siswa dengan penggunaan alat belajar yang intuitif. Hasilnya adalah software belajar yang secara eksplisit membantu proses belajar dengan menghasilkan dokumen proyek untuk membantu pemahaman konsep Manajemen Proyek dan antarmuka pengguna yang interaktif dan mudah digunakan untuk memotivasi proses belajar.
\end{abstract}

Kata kunci: Manajemen Proyek, Sistem Informasi, Pembelajaran Berbasis Siswa, Self-Regulated Learning , Proses Pembelajaran

\begin{abstract}
Failing IT Projects has kept growing over the past recent years. Understanding of Project Management concepts must be taught in college. Recent studies at the conducted courses at college X in Jakarta over the past ten years has shown discrepancy between daily exercises with the exam result students received. Therefore, developing a new learning process is required to enhance the student's understanding of Project Management concepts. Self-Regulated Learning method encompasses independent learning by metacognition, motivation, self-regulation, and self-evaluation. To develop such process would require a learning tools during the learning process. The technical specification for the learning tools in question needs to enable metacognition process by directing the students towards the learning steps and motivates the students by intuitive use of learning tools. The results is a learning software that explicitly help the learning process by generating project documents to help understanding Project Management concept and interactive user interface that is easy to use and motivates the learning process.
\end{abstract}

Keywords: Project Management, Information System, Student Centered Learning, Self-Regulated Learning, Learning Process.

\section{PENDAHULUAN}

Beberapa tahun belakangan ini banyak sekali investasi terhadap proyek-proyek IT yang mengalami kegagalan pada saat perencanaan ataupun pada saat implementasi proyek tengah berjalan (Marchewka, 2014). Hal ini tidak hanya merugikan investor proyek tetapi juga berdampak pada kepercayaan publik terhadap keberhasilan investasi proyek Sistem Informasi (Straub, Kerlin, \& Whalen, 2017). Melihat hal ini mendorong keharusan agar Manajemen Proyek dikuasai oleh mahasiswa dalam studi S1 Teknik Informatika dan Sistem Informasi. Akan tetapi hasil studi perkuliahan Manajemen Proyek Sistem Informasi (MPSI) di perguruan tinggi swasta X di Jakarta dalam sepuluh tahun belakangan ini menunjukkan kesenjangan antara hasil belajar harian dengan 
nilai ujian yang mahasiswa dapatkan. Gambar 1 dan 2 menunjukkan grafik dari perkuliahan ratarata Manajemen Proyek Sistem Informasi yang berlangsung di perguruan tinggi swasta $\mathrm{X}$ di Jakarta selama sepuluh tahun silam. Dengan menghilangkan semua asumsi seperti pengaruh dari kemampuan mengajar dosen, kemampuan mahasiswa menerima materi, perubahan kurikulum, pembobotan nilai, dan lain-lain. Terdapat penurunan nilai akhir yang cukup terlihat dalam beberapa tahun belakangan ini. Penyebabnya dapat terlihat pada nilai UTS yang cukup rendah dan nilai UAS yang hampir sama rendahnya. Akan tetapi terdapat kejanggalan ketika hasil ujian tersebut dibandingkan dengan hasil nilai harian. Ini menunjukkan kejanggalan dalam kinerja harian mahasiswa dibandingkan ujian mereka. Oleh karena itu proses belajar Manajemen Proyek harus ditingkatkan.

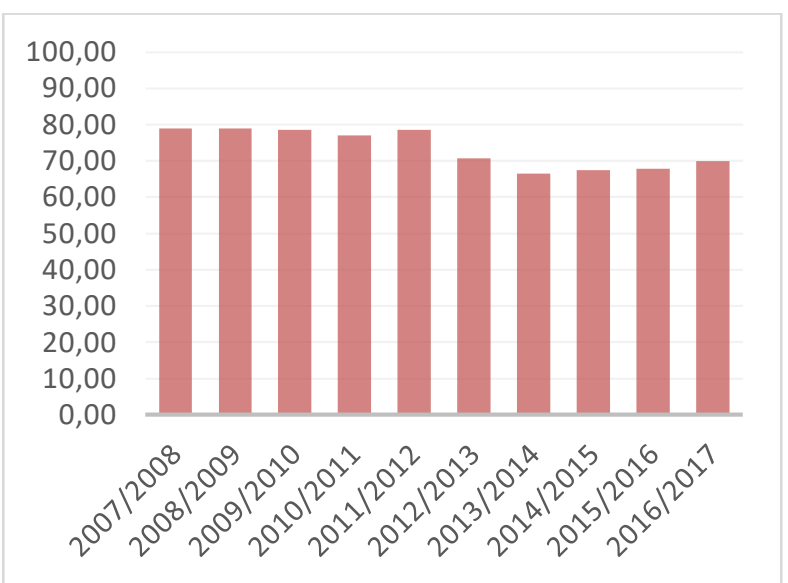

Sumber: (Febrianto \& Fadhillah, 2018)

Gambar 1. Nilai Akhir Rata-Rata Perkuliahan MPSI di PTS X, Jakarta

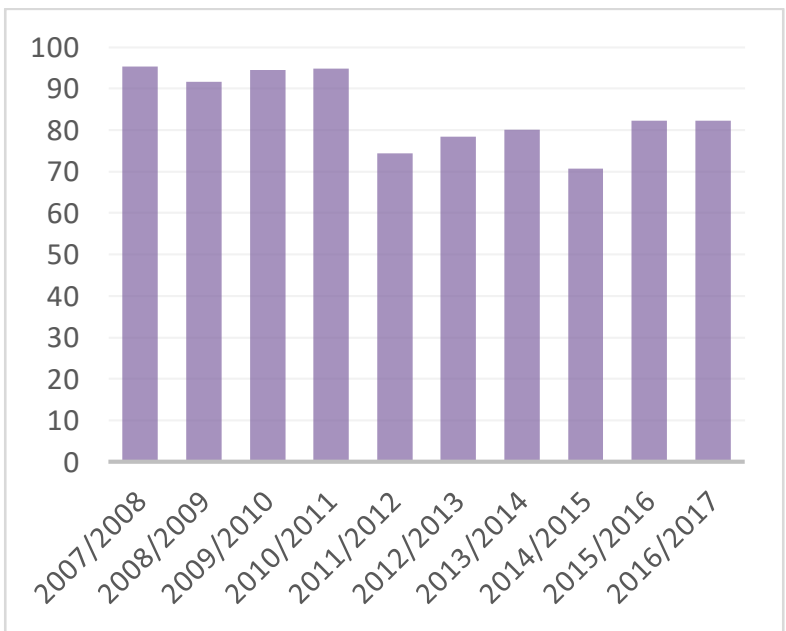

Sumber: (Febrianto \& Fadhillah, 2018)

Gambar 2. Nilai Harian Perkuliahan MPSI di PTS X, Jakarta

\section{Ranah Konsep Manajemen Proyek}

Konsep Manajemen Proyek yang diajarkan pada PTS X di Jakarta mengacu pada buku panduan Project Management Body of Knowledge (PMBOK) (Project Management Institute, 2017) Di dalam panduan PMBOK terdapat 10 ranah konsep dari Manajemen Proyek yang dibagi menjadi 49 proses dan dikelompokkan ke dalam 5 tahapan proses yaitu: (1) Inisiasi; (2) Perencanaan; (3) Eksekusi; (4) Pengawasan; dan (5) Penutup; Penjabaran lengkap dari proses-proses tersebut dapat dilihat pada Lampiran Tabel I.

\section{Sistem Perkuliahan yang Berjalan}

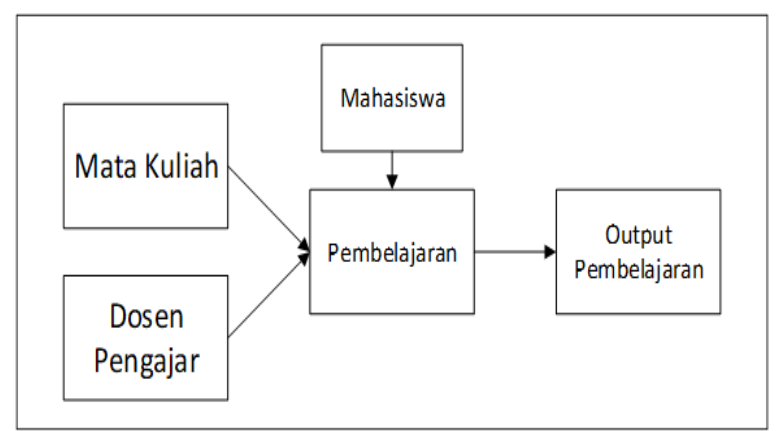

Sumber: (Febrianto \& Fadhillah, 2018)

Gambar 3. Proses Perkuliahan MPSI di PTS X Jakarta

Pada gambar 5 di atas, pembelajaran merupakan gabungan antara mata kuliah yang disusun sesuai dengan silabus rencana perkuliahan, jadwal pertemuan, dan total kelas yang diajarkan dengan dosen pengajar yang mengajar di perguruan tinggi swasta X di Jakarta. Setelah melewati proses pembelajaran, mahasiswa kemudian diarahkan untuk menghasilkan output pembelajaran mereka selama berkuliah, seperti tugas harian, UTS dan UAS.

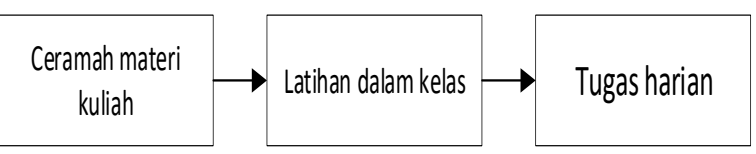

Sumber: (Febrianto \& Fadhillah, 2018)

Gambar 4. Proses Pembelajaran Dalam Kelas

Dalam kelas perkuliahan mahasiswa menerima ceramah konsep soal teori Manajemen Proyek sesuai dengan rencana perkuliahan. Konsep tersebut kemudian diperkuat dengan latihan dalam kelas dan tugas harian. Tugas harian yang diberikan merupakan implementasi dari konsep Manajemen Proyek yang dalam hal ini adalah Dokumen proses Manajemen Proyek dengan urutan sebagai berikut: 


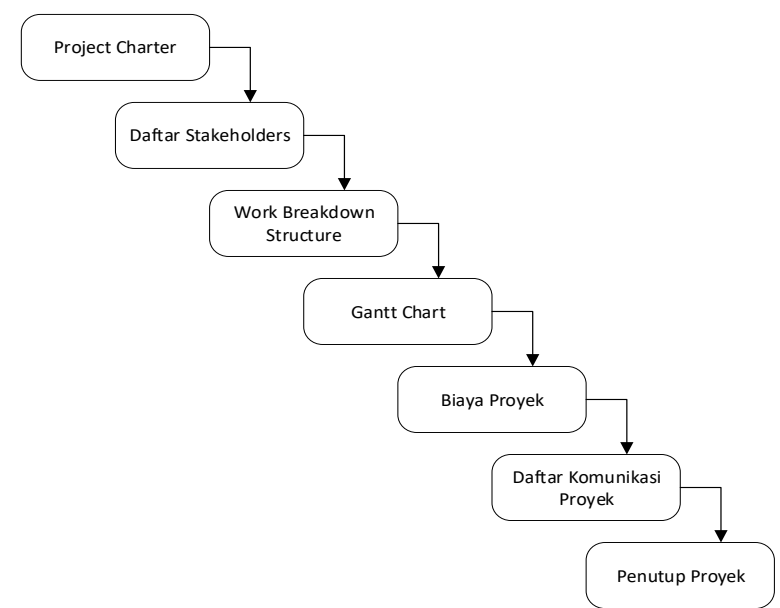

Sumber: (Febrianto \& Fadhillah, 2018)

Gambar 5. Alur Dokumen Tugas Harian

\section{METODE PENELITIAN}

Metodologi penelitian untuk menemukan solusi dari permasalahan proses belajar adalah sebagai berikut:

\section{Metode Self-Regulated Learning}

Metode Self-Regulated Learning adalah metode belajar mandiri dengan terus melakukan penyesuaian terhadap hasil belajar yang dicapai dengan tujuan akhir dari proses belajar melalui perencanaan, pengaturan, dan evaluasi (Nilson, 2013) (Kizilcec, Pérez-Sanagustín, \& Maldonado, 2017). Metode SRL terdiri dari 4 parameter yaitu: (1) Metakognisi; (2) Motivasi; (3) Pengaturan Diri; dan (4) Evaluasi diri; yang direpresentasikan dengan gambar berikut:

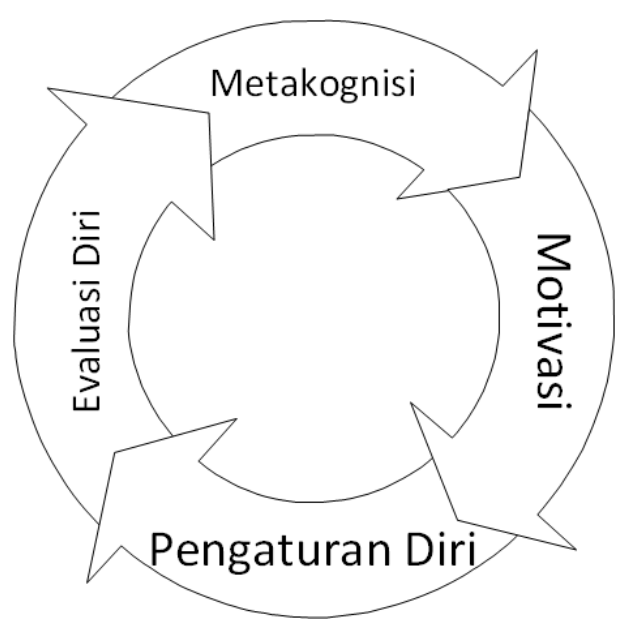

Sumber: (Febrianto \& Fadhillah, 2018)

Gambar 6. Komponen-komponen dalam Self-Regulated Learning
Manfaat dari metode SRL adalah peningkatan dalam performa belajar, percaya diri bertambah, kesadaran akan kemampuan diri, pengendalian stress, dan manajemen diri yang lebih baik (Nilson, 2013). Melihat akan manfaatnya dan kegunaannya dalam perkuliahan. Membuat metode ini sangat cocok untuk menjadi pendekatan utama dalam merancang proses belajar tambahan yang mengkomplemen sistem perkuliahan yang ada dengan harapan mampu meningkatkan peforma perkuliahan Manajemen Proyek Sistem Informasi di PTS X Jakarta.

\section{Spesifikasi Teknis}

Hasil wawancara dengan mahasiswa-mahasiswa yang pernah mengambil mata kuliah Manajemen Proyek Sistem Informasi, mengatakan bahwa dikarenakan tidak adanya langkah yang jelas dalam belajar membuat motivasi mereka cukup lemah selama berkuliah. Langkah yang jelas dalam belajar dapat diukur sebagai parameter metakognisi, sedangkan motivasi belajar diukur sebagai motivasi dalam SRL. Dengan demikian mendorong adanya kebutuhan untuk mengembangkan alat bantu belajar dalam bentuk E-Learning (Clark \& Mayer, 2016) yang dapat memberikan metakognisi dan motivasi selama proses belajar berlangsung.

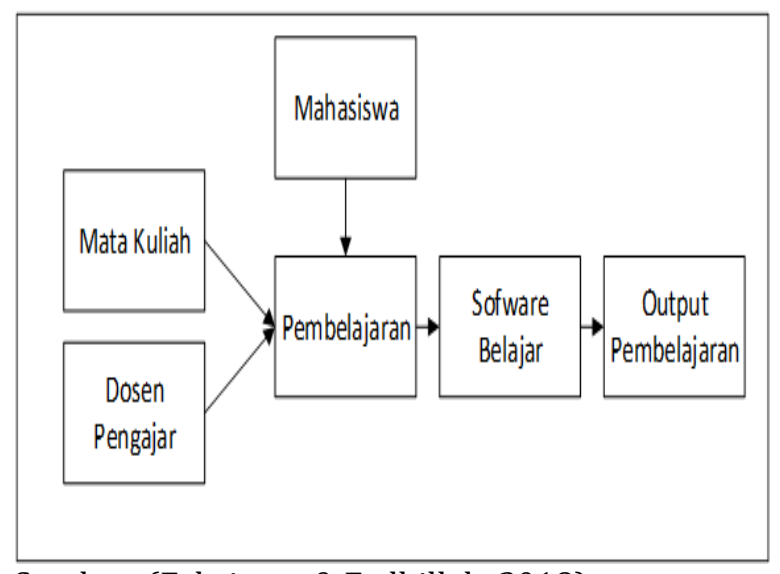

Sumber: (Febrianto \& Fadhillah, 2018)

Gambar 7. Rancangan Proses Belajar yang Diusulkan

E-Learning akan diimplementasi pada platform web untuk memanfaatkan segala kelebihan yang ditawarkan oleh web ketimbang oleh desktop (Broadbent \& Poon, 2015). Tidak hanya itu spesifikasi kebutuhan software lebih lanjut adalah sebagai berikut:

- Berjalan pada platform web.

- Mengarahkan mahasiswa dalam langkahlangkah pembuatan dokumen proyek. 
- Rancangan antarmuka akan mengacu kepada 8 Golden Rules of Interface Design (Shneiderman, Plaisant, Cohen, Jacobs, \& Elmqvist, 2016)

- Dokumen proyek dalam proses belajar mencakup (1) Project Charter; (2) Daftar Stakeholders; (3) Gantt Chart; (4) WBS; (5) Biaya Proyek; (6) Komunikasi Proyek; dan (7) Penutup Proyek;

- Dokumen proyek dalam proses akan dihasilkan dalam format .pdf.

- Membangkitkan motivasi belajar.

\section{Metode Rapid Application Development}

Dengan spesifikasi software tersebut maka metode Rapid Application Development (RAD) dipilih sebagai metode pengembangan software web belajar. Metode RAD terdiri atas 4 proses yaitu: (1) Analisa kebutuhan; (2) Rancangan software; (3) Coding; serta (4) Perpindahan cepat (cutover); dalam rentang waktu yang cukup singkat yang disebut juga dengan timebox (Isaias \& Issa, 2015)

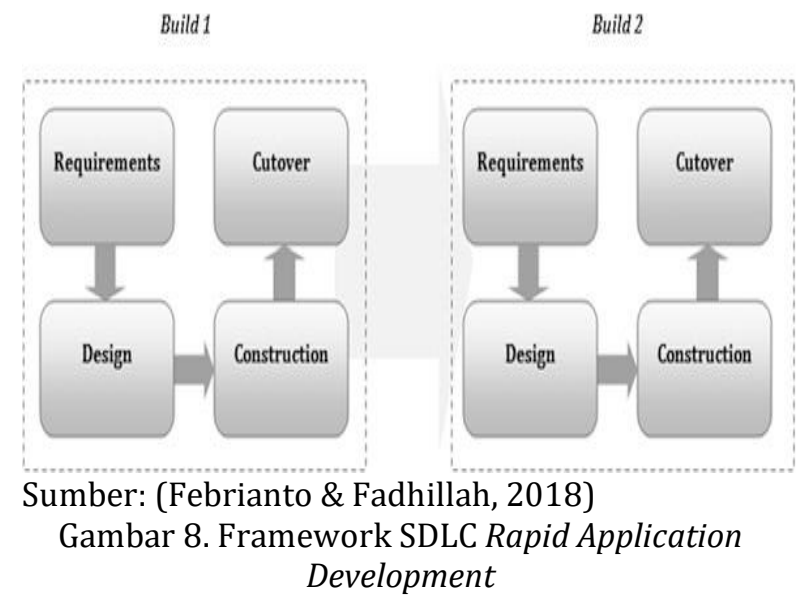

Metode SDLC ini dianggap sesuai untuk pengerjaan software dikarenakan tingkat kesulitan dari web belajar cukup sederhana, dan waktu pengerjaan yang relatif singkat. Maka dari itu timebox untuk pengerjaan metode RAD sendiri akan berkisar sekitar 2-3 minggu. Dengan estimasi jumlah timebox yang akan digunakan sebanyak 2 timebox.

\section{HASIL PENELITIAN DAN PEMBAHASAN}

Hasil dari rancangan software adalah sebuah web belajar yang dapat diakses dengan menggunakan browser baik secara lokal maupun online dengan rancangan tampilan yang mengikuti pedoman 8 Golden Rules of Interface Design (Shneiderman et al., 2016). Tidak hanya itu web juga mampu melakukan proses pembuatan dokumen Manajemen Proyek dengan mengandalkan input dari pengguna serta mampu menyimpan data tersebut ke dalam browser.

Analisis dari implementasi software belajar mengacu kepada spesifikasi software yang telah ditetapkan sebelumnya. Beberapa dari spesifikasi tersebut pada tabel 1 berikut:

Tabel 1. Implementasi Spesifikasi Website Belajar

\begin{tabular}{lr}
\hline $\begin{array}{l}\text { Spesifikasi Website } \\
\text { Belajar }\end{array}$ & Status Implementasi \\
\hline $\begin{array}{l}\text { Berjalan pada platform } \\
\text { web. }\end{array}$ & $\begin{array}{r}\text { Sudah } \\
\text { Dekimplementasi }\end{array}$ \\
\hline $\begin{array}{l}\text { Dokumen proyek dalam } \\
\text { proses akan dihasilkan } \\
\text { dalam format.pdf. }\end{array}$ & $\begin{array}{r}\text { Sudah } \\
\text { Terimplementasi }\end{array}$ \\
\hline $\begin{array}{l}\text { Dokumen proyek dalam } \\
\text { proses belajar mencakup }\end{array}$ & Terimplementasi \\
$\begin{array}{l}\text { (1) Project Charter; (2) } \\
\text { Daftar Stakeholders; (3) }\end{array}$ & \\
Gantt Chart; (4) WBS; (5) & \\
$\begin{array}{l}\text { Biaya Proyek; (6) } \\
\text { Komunikasi Proyek; dan } \\
\text { (7) Penutup Proyek; }\end{array}$ & \\
\hline Sumber: (Febrianto \& Fadhillah, 2018)
\end{tabular}

Untuk lebih lanjut lagi ada beberapa spesifikasi lainnya yang membutuhkan pembahasan lebih mendalam di antaranya adalah:

\section{Mengarahkan Mahasiswa Dalam Langkah- Langkah Pembuatan Dokumen Proyek}

Website alat belajar diawali dengan halaman dashboard yang informatif, dengan memberikan penjelasan sekilas perihal dokumen proyek yang dapat dibuat dan dengan alur halaman web yang sederhana membuat langkah-langkah pembuatan dokumen terarah dengan baik.

\section{Rancangan antarmuka mengacu kepada 8 Golden Rules of Interface Design}

Berikut adalah implementasi rancangan antarmuka dikaitkan dengan 8 aturan emas rancangan antarmuka (Shneiderman et al., 2016)

Tabel 2. Kriteria 8 Aturan Emas Rancangan Antarmuka dan Status Implementasinya

\begin{tabular}{lr}
\hline $8 \quad$ Aturan Emas & Website Belajar \\
Rancangan antarmuka & Sudah \\
\hline $\begin{array}{l}\text { Mempertahankan } \\
\text { konsistensi. }\end{array}$ & Terimplementasi \\
\hline $\begin{array}{l}\text { Kejar pengunaan secara } \\
\text { universal. }\end{array}$ & Belum \\
\hline
\end{tabular}




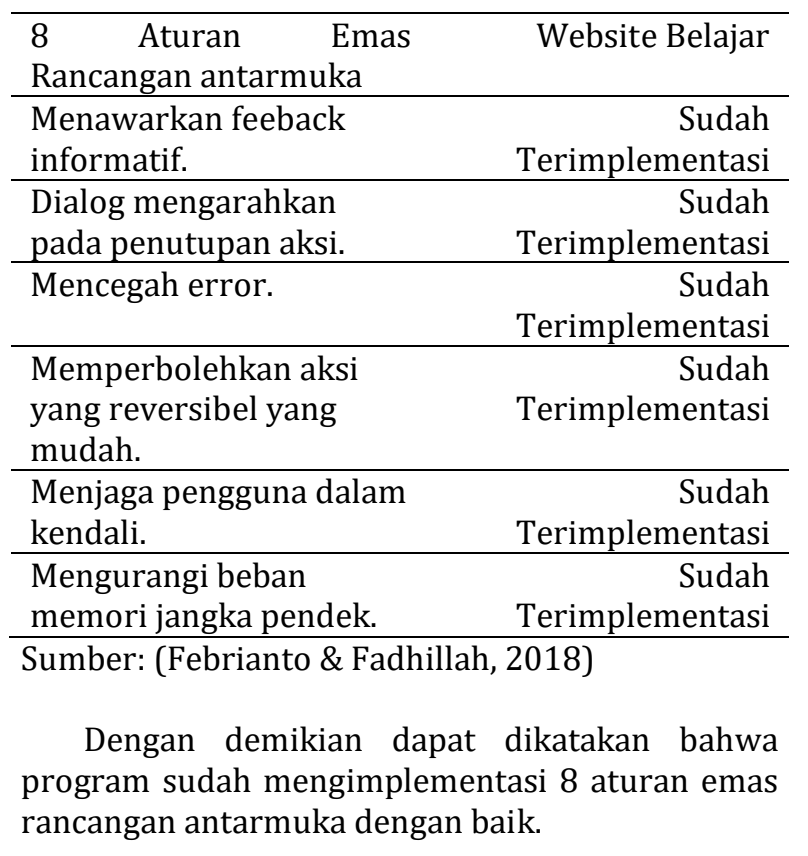

\section{Membangkitkan Motivasi Belajar}

Dengan langkah-langkah pembuatan dokumen yang terarah dengan baik, maka mahasiswa mampu dengan mudah menetapkan strategi belajar yang cocok untuk mereka gunakan. Tidak hanya itu, dengan tampilan sederhana dan menarik pengguna dapat meningkatkan motivasi siswa untuk menggunakan alat belajar.

\section{KESIMPULAN}

Beberapa kesimpulan yang diambil dari penelitian ini adalah mahasiswa dapat memiliki langkah-langkah yang jelas dalam mempelajari Manajemen Proyek jika mereka diarahkan untuk menyusun langsung dokumen-dokumen Manajemen Proyek tersebut secara rapi dan terstruktur. Alat belajar yang dibangun pada penelitian ini mendukung proses pembelajaran dengan secara eksplisit terlibat dalam proses pembelajaran. Dalam hal ini adalah proses pembuatan dokumen Manajemen Proyek melalui input pengguna. Dalam proses pembelajaran perlunya perubahan dalam kurikulum dan penambahan materi praktikum. Proses belajar Manajemen Proyek dapat dibuat menarik dan lebih mudah dipahami mahasiswa dengan membuat proses belajar melalui interaksiinteraksi yang terarah dan panduan yang jelas, disertai dengan estetika tampilan program yang modern, sederhana dan konsisten.

\section{REFERENSI}

Broadbent, J., \& Poon, W. L. (2015). Self-regulated learning strategies \&amp; academic achievement in online higher education learning environments: A systematic review. The Internet and Higher Education, 27, 1-13. https://doi.org/10.1016/J.IHEDUC.2015.04. 007

Clark, R. C., \& Mayer, R. E. (2016). E-learning and the science of instruction: proven guidelines for consumers and designers of multimedia learning. New Jersey: Wiley.

Febrianto, K., \& Fadhillah, Y. (2018). Laporan Akhir Penelitian - Implementasi Self-Regulated Learing Pada Aplikasi Pembelajaran Manajemen Proyek Sistem Informasi Pada Perguruan Tinggi Swasta X Di Jakarta. Jakarta.

Isaias, P., \& Issa, T. (2015). High Level Models and Methodologies for Information Systems. New York, NY: Springer New York. https://doi.org/10.1007/978-1-4614-92542

Kizilcec, R. F., Pérez-Sanagustín, M., \& Maldonado, J. J. (2017). Self-regulated learning strategies predict learner behavior and goal attainment in Massive Open Online Courses. Computers \& Education, 104, 18-33. https://doi.org/10.1016/J.COMPEDU.2016.1 0.001

Marchewka, J. T. (2014). Information Technology Project Management: providing measurable organizational value. New Jersey: John Wiley \& Sons.

Nilson, L. (2013). Creating self-regulated learners: Strategies to strengthen students? selfawareness and learning skills. Virginia: Stylus Publishing, LLC.

Project Management Institute. (2017). A guide to the project management body of knowledge (PMBOK guide) (6th ed.). Pennsylvania: Project Management Institute.

Shneiderman, B., Plaisant, C., Cohen, M., Jacobs, S. M., \& Elmqvist, N. (2016). Designing the user interface: strategies for effective humancomputer interaction (6th ed.). London: Pearson. 
Straub, J., Kerlin, S., \& Whalen, D. (2017). Teaching software project management using project based learning (PBL) and group projects. In 2017 IEEE International Conference on Electro Information Technology (EIT) (pp. 016-021). IEEE. https://doi.org/10.1109/EIT.2017.8053323 